\title{
THE FEATURES OF LABOR EMIGRATION FROM THE SLOVAK REPUBLIC
}

\author{
Adriana GRENČIKOVÁ ${ }^{1}$, Ilona SKAČKAUSKIENĖ ${ }^{2}$, Jana ŠPANKOVÁ ${ }^{3}$ \\ ${ }^{1,3}$ Alexander Dubček University of Trenčín, Trenčín, Slovakia \\ ${ }^{2}$ Vilnius Gediminas Technical University, Vilnius, Lithuania \\ E-mails: ${ }^{1}$ adriana.grencikova@tnuni.sk; ${ }^{2}$ ilona.skackauskiene@vgtu.lt (corresponding author); \\ 3jana.spankova@tnuni.sk
}

Received 17 April 2018; accepted 23 October 2018

\begin{abstract}
Migration is historically a social phenomenon that not only has a significant effect on politics, economics, and social aspects but also presents challenges to the security of states and alters population composition in countries. Labor migration and its investigation are becoming a society-wide phenomenon because of the labor force shortage as well as the aging population. The Slovak Republic is a country that faces the outflow of qualified workers abroad, and the country's index of aging is one of the most dynamic in Europe. The current study aims at examining the relations and the reasons for emigration to work from the Slovak Republic. To identify the causes of labor emigration in the Slovak Republic, a survey was conducted to explore the decisions of people to emigrate for work, the duration of the stay abroad and the possibility of returning to Slovakia. This study also analyses the relationship between GDP growth and improvement of the economic situation in Slovakia, the number of labor emigrants, as well as the relationship between the minimum wage and the number of labor migrants.
\end{abstract}

Keywords: migration, labor emigration, reasons for emigration, the minimum wage.

JEL Classification: J11, F22, J61, J80.

\section{Introduction}

Approximately $3.3 \%$ (or 258 million people in 2017) of the world population lives in a country other than their country of origin (Mboup 2018). Since the European Union (EU) citizens have the right to free movement, settlement and employment across the EU, this has led to increased labor mobility between member states. Migration flows over past decades among EU member states and in- and outside of the EU have had a significant impact on the current population size in the most countries: 4.3 million people immigrated to one of the EU-28 member states during 2016 (Eurostat 2018). Emigration from the Central and Eastern Europeans is very visible (Szarucki et al. 2016), with the particular emphasis on Romanians, Lithuanians, Latvians, Hungarian, Croatian and Slovaks.

Migration - a change of usual residence to a different country - has positive and negative impacts for both the country of origin and the country of immigration. For the latter, it holds potential value for economic growth by introducing new ideas from around the world as well as diverse cultural heritage and thinking (Yeasmin 2016), but for the sending country it may cause the effects of 'brain drain'. The Slovak Republic is a country that faces the outflow of qualified workers abroad, and the index of aging is one of the most dynamic in Europe. In that light, the authors have designed this study to examine the link and the reasons for emigration to work from the Slovak Republic. For the purpose of the article the authors examined the reasons for the decisions of people to emigrate for work, duration of stay abroad, the possibility of returning to Slovakia, the relationship between GDP growth and improvement of the economic situation in Slovakia and the number of emigrants to work abroad, the relationship between the minimum wage and the number of labor emigrants. The article relies upon findings of a survey of

Copyright $\odot 2018$ The Authors. Published by VGTU Press.

This is an Open Access article distributed under the terms of the Creative Commons Attribution License (http://creativecommons.org/licenses/by/4.0/), which permits unrestricted use, distribution, and reproduction in any medium, provided the original author and source are credited.. 
emigrated people conducted in Slovakia in 2016 and includes correlation analysis as well.

The paper is organized as follows. Firstly, we review the theoretical background of labor migration, thus allow us to indicate the main factors for emigration. Then we describe the research methodology, including the possible limitations of methods. The empirical analysis is described in the third section, while the last section concludes the paper.

\section{Theoretical discussion}

Migration is a phenomenon so extensive that it is not practicable to define it by using one theory. There are several theories that can build on each other, but because of different views on the causes of migration in the various scientific disciplines, some theories can be mutually exclusive (Bilan and Cabelkova 2015, Böcker 1994, Czaika 2015).

Bahna (2011) defines migration as "the process of relocation of people outside the territory of residence, permanent or temporary, for a longer or shorter period of time". Migration is also a response to changes in living conditions, caused by population growth, development of production and trade, formation of countries, states, nations, climatic conditions, as well as violent causes, such as war (Thomas 2016, Divinský 2005, Vojtovič 2013, Strielkowskia and Bilan 2016, Zabarauskaitė and Skačkauskienė 2014). Jeníček and Foltýnet (2010) considers migration as a "reaction of humanity on unequal distribution of resources, services and opportunities". According to Bolečeková (2010), migration is the subject of the examination of several scientific disciplines as a multidimensional phenomenon, especially demography, sociology, international relations, international law, geography and others, but international migration is moving people, that they are crossing borders, in order to settle in a country other than the country of origin for a long time.

Professional literature provides many breakdowns of migration. According to Benda (2011), migration is divided into external (abroad) and internal. External migration represents a "movement of persons across administrative borders of the states to take up residence permanently or temporarily in the other country" (Bolečeková 2010). Internal migration is understood as a "move in a defined territory, without exceeding its boundaries (e.g., in the intentions of state or the same region)" (Jurčová 2005). The author emphasizes that internal migration has a decisive influence on the gains and losses of population in the various regions in this context.

Mobility and migration of a labor force are used many times as synonyms in the literature, but we have to distinguish between them. Labor force mobility means any spatial movement of production factor "work". "Migration has stable character because the parallel change of residence takes place in this case. On the contrary, there is an ongoing spatial movement of labor without a change of residence, it is a spatial (intraregional and interregional) commuting" (Saleh Mothana 2007).

Labor migration is part of international migration which became of great importance. A person who wishes to actively carry out some work in the country where the person is not a citizen and a person receives an appropriate reward in the form of wages and salary, we refer to as the migrant for work. Immigrant for work means a person who immigrates to the country, mainly due to finding decent jobs. Emigrant for work means that inhabitant who left either temporarily or permanently, the country with the intent to carry out specific work abroad. We considered labor migrant person as a person enters in the country as a foreign labor force with an invitation from the government or their future employer. It can also be a person who entered the territory of the country for this purpose, to find work abroad (Divinský 2005).

The difference between labor migration and economic migration is the motive - for economic migration the motive is the desire for better living conditions, mainly economic and social, a prerequisite for obtaining them is not necessarily the exclusively change jobs. On the contrary, labor migration is linked solely with jobs, but it can be seen as a subset of economic migration, i.e., is an expression of efforts to improve living conditions through labor migration (Bolečeková 2010).

Researchers (Baršová and Barša 2005) divided labor migration as permanent and temporary. In case of permanent labor migration is migrant, who settled in the country to which they went for work together with their families. For temporary labor migration is a social response on needs of the labor market, these needs cannot be covered from domestic sources for various reasons. Various common goals are monitored in these types of labor migration. Promoting economic development of the country and population growth are notably monitoring for the permanent labor migration and temporary migration. It focuses on the substitution of a number of employees on unfilled vacancies in the labor market, in particular.

Literature review on labor migration has revealed both negative and positive impacts, both in the country of origin and the country of immigration. Among one of the negative impacts of labor migration, we can include 'brain drain' outside the country of the state. Emigration may have the direct effect of decreasing the average human capital in regions of origin (Anelli and Peri 2017). Particularly developing of countries loses out because leakage of the highly qualified workforce, these countries have high costs of education of young people, young people leave the country after graduation, and those countries lose benefits that these educated people could create. In this case, we can talk about the negative impacts of labor migration, which represents some economic loss for the country. It should also be noted that this is a severe problem because the educated and highly skilled 
population is a certain degree of success, prosperity for the country and it is a reflection of certain level of countries (Czaika and de Haas 2013, Bilan 2012, Čajka et al. 2014).

Another negative impact for the country is the fact that the leakage of highly qualified of a labor force abroad does not increase the average level of qualification of the population in a given country, but it supports the development of the country from which labor force leaked. Leakage of the population for work can have a negative impact on the demographic development of the country. The fact that many young people leave to work abroad, it has a significant share of the postponement of marriage and found a family in later age. Wage growth is a positive as well negative side of labor migration, growth is a result of the reduction of individual labor supply on the one hand, it affects the growth of wages in a given country, but it causes an increase in inequality, which has a negative impact on the labor market on the other hand. The fact that many young people leave for jobs abroad can sometimes have a positive effect on a given country, in the sense that it does partially address the unemployment problem of the excess workforce, and it also reduces social tensions in a given country. Family reunification is often the consequence of labor migration, i.e., many people come abroad for their families that they have settled here already and immigrant countries must grant them permanent residence in this country (Divinský 2011, Ortega and Peri 2013). Remittances are another consequence of labor migration that affects the country in the right direction. Financial remittances are revenues earned abroad, which, residents sent or used in their country of origin. This income sends from abroad to the country of origin influences and thus increases the standard of living, social standards and purchasing power of the population in this country. Social remittances are the no less important role, i.e., those values, abilities, and skills that inhabitants acquire abroad and then will bring to the country of origin (Soroková 2010). Worth to mention that the movement of people towards prosperous economies can create networks that act as channels for modernization expatriates may put pressure on the government of origin to increase accountability and improve governance (Anelli and Peri 2017).

\section{Research methodology}

Leakage of labor force abroad begins to be a severe problem for the economy of the Slovak Republic. For this reason, we had set a clarification of selected indicators as an objective in this study, and indicators affect the decision to offer its labor force work in foreign labor markets. Several methods are used in the paper - from comparative analysis to the questionnaire and statistical methods. The method of questionnaire was used to obtain the opinions of Slovak emigrants. Emigration is the phenomenon that is the most difficult to estimate, the sample surveys are the main source of emigration data today (Willekens et al. 2017). Worth to mention that surveys may record emigration intentions, but intentions are often not good predictors of behavior. Despite this limitation, emigration research has often focused on intentions rather than actual behavior (Dibeh et al. 2018). Sample survey respondents were Slovaks, who have gone to work abroad in the years 1998-2016. The survey was conducted in March to July 2016. The survey sample was calculated using a $99 \%$ tolerance interval according to the following formula (Pabedinskaite and Činčikaitè 2016):

$$
n=\frac{N \times 2.58^{2} \times p \times q}{\varepsilon^{2} \times(N-1)+2.58 \times p \times q},
$$

where $N$ - size of the population; $\varepsilon$ - desired confidence $(\varepsilon=$ $9 \%) ; p=q=50 \%$ - probability that the event will occur/ will not occur; $99 \%$ of the normal distribution is within 2.58 standard deviations.

According to the data provided by the Statistics office, at the end of 2016, there were 160.0 thousand emigrants in Slovakia. Basing on formula (1), a required number of respondents is 205 . A total of 250 questionnaires were distributed, completed and returned questionnaires were 244 . The rate of return was $98 \%$. Respondents filled out the questionnaire anonymously. The questionnaire was composed of 12 items, of which one item was opened, two - closed with the simple choice questions, one - closed with multiple choice answers. Eight items were semi-open with the possibility to add their own answers. Each entry was evaluated separately by gender of respondents, their age, educational attainment, the residence of respondents in Slovakia and the year in which respondents began to work abroad. Additional answers were ranked in order from most frequently occurring to least occurring and answers were evaluated individually by all above-mentioned criteria in semi-open items. We evaluated only some selected questions in our study. 113 (46\%) women and 131 (54\%) men answered the survey. Most respondents were at the age of $30-40$ years ( $55 \%$ of all respondents), $59 \%$ were secondary education, $41 \%$ with university education. Respondents were not recorded under the age of 20 years and above 50 years.

We used the method of correlation for verification of some dependencies. The correlation coefficient $r$ represents the linear dependence between two variables. We obtain the coefficient of determination, with exponentiation of $r$, which represents the proportion of common dispersion, so that is information about the strength of relations between variables. The significance of correlation is basic information about its reliabilities. The test of significance is based on the assumption that the collocation of residual values for the dependent variable $y$ is normal, and the variability of these values is the same for all values of the independent variable $x$. 
The intensity of linkages between variables can be:

$-r= \pm 0,01-0,29-$ no correlation

$-r= \pm 0,3-0,69-$ weak correlation

$-r= \pm 0,7-0,89$ - moderate correlation

- $r= \pm 0,9-0,99$ - strong correlation

We were counting the dependency ratio (correlation coefficient) by using function CORREL in Microsoft Excel.

\section{Results of the empirical analysis}

The analysis was also focused on the structure of the respondents, which we get in the questionnaire survey. People in the age group 30-40 years and secondary education formed the largest representation (see Table 1). This age period is a period of building a career and background in personal life. We assume that if they launch the careers in the foreign labor market, so they will not think about returning to Slovakia.

During the survey, respondents were asked to indicate the year they started to work abroad. Migration for work is increasing, most respondents left in 2015 (32 respondents,

Table 1. Structure of respondents by sex, age group and education (source: own processing)

\begin{tabular}{|l|c|c|c|c|c|c|}
\hline \multirow{2}{*}{$\begin{array}{l}\text { Charac- } \\
\text { teristics }\end{array}$} & \multicolumn{2}{|c|}{ under 20 years old } & \multicolumn{2}{|c|}{ 20-30 years old } & \multicolumn{2}{|c|}{$30-40$ years old } \\
\cline { 2 - 8 } Men & 0 & 0 & 37 & 8 & 28 & 36 \\
\hline Women & 0 & 0 & 37 & 4 & 26 & 44 \\
\hline Total & 0 & 0 & 74 & 12 & 54 & 80 \\
\hline Total & \multicolumn{3}{|c|}{0} & \multicolumn{2}{|c|}{86} & \multicolumn{2}{|c|}{134} \\
\hline \multirow{5}{*yyyyyyy}{} & $40-50$ years old & over 50 years old & \multicolumn{2}{|c|}{ Total } \\
\cline { 2 - 8 } & SE & UNI & SE & UNI & SE & UNI \\
\hline Men & 16 & 6 & 0 & 0 & 81 & 50 \\
\hline Women & 0 & 0 & 0 & 0 & 63 & 50 \\
\hline Total & 16 & 8 & 0 & 0 & 144 & 100 \\
\hline Total & \multicolumn{2}{|c|}{24} & \multicolumn{2}{|c|}{0} & \multicolumn{2}{|c}{244} \\
\hline
\end{tabular}

SE - secondary education, UNI - university education

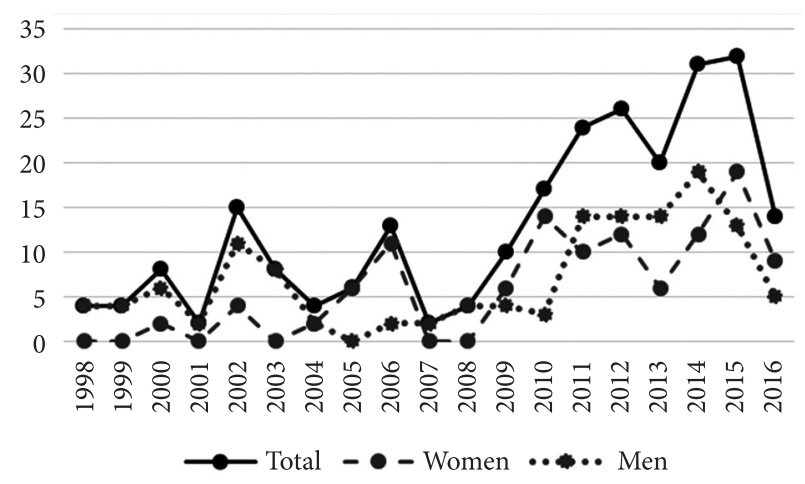

Figure 1. The number of respondents in the year in which they started to work abroad (source: own processing) which is $13 \%$ of all respondents), at least in 2001 and 2007 (1 respondent). The Figure 1 shows that the leakage to work abroad has decreased in the group of respondents in 2016. The labor force starts to be a significant shortage in the labor market in the Slovak Republic. It means that people should not have a reason to go to work abroad.

We investigated the attractiveness of the target countries in which respondents work in our survey (see Table 2). Most of them work in the UK (nearly $21 \%$ of all respondents), at least in Canada and Sweden (both with 3.69\%). The United Kingdom's prospective withdrawal from the European Union will change the orientation of migrants in this country.

Next question sought reasons for the choice of the country (see Table 3). Respondents were allowed to select a maximum of two answers to this question. Distance from the selected country to residence showed the greatest influence in the selection of the country (53.70\% of all responses), at least the political stability of the country $(4.32 \%)$. Distance from the selected country to the residence is essential for maintaining ties and relationships with the families of respondents, with family members who stay in the Slovak Republic and

Table 2. The country in which respondents work (source: own processing)

\begin{tabular}{|l|c|c|}
\hline \multicolumn{1}{|c|}{ Country } & Number & Per cent \\
\hline Austria & 24 & 9.84 \\
\hline Canada & 9 & 3.69 \\
\hline Sweden & 9 & 3.69 \\
\hline USA & 16 & 6.56 \\
\hline UK & 51 & 20.9 \\
\hline Netherlands & 29 & 11.89 \\
\hline France & 19 & 7.79 \\
\hline Switzerland & 14 & 5.74 \\
\hline New South Wales (Australia) & 19 & 7.79 \\
\hline New Zealand & 13 & 5.33 \\
\hline Czech Republic & 19 & 7.79 \\
\hline Germany & 22 & 9.02 \\
\hline Total & 244 & 100.00 \\
\hline
\end{tabular}

Table 3. The factors affecting decision of the respondents in the selection of the country (source: own processing)

\begin{tabular}{|l|c|c|}
\hline \multicolumn{1}{|c|}{ Factor } & Number & Per cent \\
\hline Political stability of the country & 14 & 4.32 \\
\hline Economic strength of the country & 62 & 19.14 \\
\hline $\begin{array}{l}\text { Distance from the selected country } \\
\text { to residence }\end{array}$ & 174 & 53.70 \\
\hline $\begin{array}{l}\text { Social ties that are already abroad } \\
\text { (family, friends) }\end{array}$ & 74 & 22.84 \\
\hline Other & 0 & 0.00 \\
\hline Total & 324 & 100.00 \\
\hline
\end{tabular}


it may also indicate that respondents think about the return to their native country.

For the above reason, we were interested in how long the respondents are planning to spend time in the foreign labor market. Nearly $26 \%$ of respondents said that they do not intend to return to Slovakia (see Table 4 ). $23 \%$ of them plan their return under certain conditions. $50.82 \%$ of respondents plan to return to Slovakia, if the working environment will be improved in the country, nearly $30 \%$ of them have other personal reasons. $8 \%$ of respondents want to return due to a feeling of discrimination. Respondent not identified any possibility of return due to the different culture, poorer housing conditions and the implementation of less skilled labor.

The reason for returning to the home country is a very important factor in the behavior of emigrants. We had found that $50 \%$ of respondents mentioned the main reason as the improving the working environment in Slovakia (see Table 5). It opens up new questions about the price of labor, the number of contributions and the behavior of employers

Table 4. Planned duration of stay abroad (source: own processing)

\begin{tabular}{|l|c|c|}
\hline Duration of stay abroad & Number & Per cent \\
\hline $\begin{array}{l}\text { A few months, maximum } \\
\text { of one year }\end{array}$ & 39 & 15.98 \\
\hline One year to three years & 25 & 10.25 \\
\hline Three to five years & 23 & 9.43 \\
\hline Five to ten years & 27 & 11.07 \\
\hline More than ten years & 10 & 4.10 \\
\hline $\begin{array}{l}\text { I do not plan to go back } \\
\text { on Slovakia }\end{array}$ & 63 & 25.82 \\
\hline $\begin{array}{l}\text { I returned to Slovakia, } \\
\text { if ... }\end{array}$ & 57 & 23.26 \\
\hline Total & 244 & 100.00 \\
\hline
\end{tabular}

Table 5. For what reason would you return to Slovakia? (source: own processing)

\begin{tabular}{|l|c|c|}
\hline \multicolumn{1}{|c|}{ Reason } & Number & Per cent \\
\hline $\begin{array}{l}\text { Separation from family, } \\
\text { friends }\end{array}$ & 39 & 15.98 \\
\hline Different culture & 0 & 0.00 \\
\hline $\begin{array}{l}\text { Worse housing } \\
\text { conditions }\end{array}$ & 0 & 0.00 \\
\hline $\begin{array}{l}\text { The perception of } \\
\text { discrimination }\end{array}$ & 124 & 3.28 \\
\hline $\begin{array}{l}\text { Improving the working } \\
\text { environment in Slovakia }\end{array}$ & 0 & 50.82 \\
\hline $\begin{array}{l}\text { Implementation of less } \\
\text { skilled labor abroad }\end{array}$ & 73 & 0.00 \\
\hline Other personal reasons & 244 & 100.00 \\
\hline Total & & \\
\hline
\end{tabular}

Table 6. Are you generally satisfied with the work abroad (fulfilled your expectations)? (source: own processing)

\begin{tabular}{|c|c|c|c|c|c|c|}
\hline $\begin{array}{c}\text { Unit of } \\
\text { measu- } \\
\text { rement }\end{array}$ & Yes & $\begin{array}{c}\text { Rather } \\
\text { yes }\end{array}$ & $\begin{array}{c}\text { I cannot } \\
\text { judge }\end{array}$ & $\begin{array}{c}\text { Rather } \\
\text { no }\end{array}$ & No & Total \\
\hline Number & 114 & 75 & 38 & 17 & 0 & 244 \\
\hline Per cent & 46.70 & 30.70 & 15.60 & 7.00 & 0.00 & 100 \\
\hline
\end{tabular}

to their employees. We will further examine the ideas of respondents about the working environment in Slovakia.

Respondents had the opportunity to comment on how they are satisfied with the work abroad. $77.40 \%$ of all respondents were satisfied, and only $7 \%$ of respondents were rather unsatisfied, no one was unsatisfied (see Table 6). We had found that this is mainly about wages, which they compared with the Slovak market and the overall working environment in the workplace. As well as the question above also this issue will be subject to more detailed research in this area.

We examined the dependency between GDP growth and the departure time of our respondents abroad in the next part of the study (see Table 7). Even though GDP has a growing trend in the Slovak Republic, and we assumed that GDP depends with leave of respondents to foreign countries, the rate of dependence is at $r=0.706$ moderately tight. We state that correlation is significant between GDP and leave.

We examined the dependence of the growth of the minimum wage and the number of leaves of our respondents abroad also. The minimum wage has increased almost four times in the Slovak Republic since 1998, the rate of dependency of leaves of respondents is moderately tight $(r=0.720)$. Despite the fact that we assumed the correlation between variables of interest, we state that correlation is significant between the minimum wage and leaves.

The average wage was another factor, which we had assumed that it relates with leaving of respondents. Average wages grew by more than 2.5 times since 1998. Ratio of dependency is moderately tight $(r=0.742)$. We state that the correlation is significant between the average wage and leaves.

Regulation on minimum wage applies in Germany since 2015 , with the result that our employers had to equalize wages of workers operating in Germany and they have to pay minimum 8.50 euro per hour. Institute of minimum hourly wage implemented subsequently by other countries (e.g., France, Austria, Italy, Netherlands). We could focus on the impact of these factors on the leaves of people abroad in the future.

\section{Conclusions}

Summing up the results of the theoretical analysis we define labor migration as a movement of persons either temporarily or permanently from the country of residence with the intent to carry out specific work abroad. Migration is historically a social phenomenon that affects politics, 
Table 7. Leaves of respondents, GDP of Slovakia, minimum and average wage (source: Statistical Office of the SR (2013), own processing)

\begin{tabular}{|c|c|c|c|c|c|c|c|c|c|}
\hline \multirow[t]{2}{*}{$n$} & \multirow[t]{2}{*}{ Year } & \multicolumn{2}{|c|}{$\begin{array}{l}\text { The number of respondents who } \\
\text { began working abroad in a given year }\end{array}$} & \multicolumn{2}{|c|}{$\begin{array}{l}\text { GDP of the SR } \\
\text { (mil. EUR) }\end{array}$} & \multicolumn{2}{|c|}{$\begin{array}{l}\text { Minimum wage } \\
\text { in } \mathrm{SR}^{*} \text { (EUR) }\end{array}$} & \multicolumn{2}{|c|}{$\begin{array}{l}\text { Average wage } \\
\text { in SR (EUR) }\end{array}$} \\
\hline & & $x_{i}$ & $x_{i}-x^{\prime}$ & $y_{i}$ & $y_{i}-y^{\prime}$ & $y_{i}$ & $y_{i}-y^{\prime}$ & $y_{i}$ & $y_{i}-y^{\prime}$ \\
\hline 1 & 1998 & 4 & -8.78 & 25395 & -28180 & 99.6 & -142.57 & 332.04 & -240.35 \\
\hline 2 & 1999 & 4 & -8.78 & 26609 & -26966 & 114.5 & -127.67 & 356.1 & -216.29 \\
\hline 3 & 2000 & 8 & -4.78 & 28893 & -24682 & 136.1 & -106.07 & 379.41 & -192.98 \\
\hline 4 & 2001 & 2 & -10.78 & 32649 & -20926 & 149.5 & -92.67 & 410.44 & -161.95 \\
\hline 5 & 2002 & 15 & 2.22 & 35862 & -17713 & 168.7 & -73.47 & 448.48 & -123.91 \\
\hline 6 & 2003 & 8 & -4.78 & 39293 & -14282 & 189.1 & -53.07 & 476.83 & -95.56 \\
\hline 7 & 2004 & 4 & -8.78 & 43582 & -9993 & 205.3 & -36.87 & 525.29 & -47.10 \\
\hline 8 & 2005 & 6 & -6.78 & 49051 & -4524 & 219.1 & -23.07 & 573.39 & 1.00 \\
\hline 9 & 2006 & 13 & 0.22 & 54515 & 940 & 234.8 & -7.37 & 622.75 & 50.36 \\
\hline 10 & 2007 & 2 & -10.78 & 62186 & 8611 & 256.4 & 14.23 & 668.72 & 96.33 \\
\hline 11 & 2008 & 4 & -8.78 & 66439 & 12864 & 268.9 & 26.73 & 723.03 & 150.64 \\
\hline 12 & 2009 & 10 & -2.78 & 64571 & 10996 & 295.5 & 53.33 & 744.5 & 172.11 \\
\hline 13 & 2010 & 17 & 4.22 & 67062 & 13487 & 307.7 & 65.53 & 769 & 196.61 \\
\hline 14 & 2011 & 24 & 11.22 & 69302 & 15727 & 317 & 74.83 & 786 & 213.61 \\
\hline 15 & 2012 & 26 & 13.22 & 71517 & 17942 & 327.2 & 85.03 & 805 & 232.61 \\
\hline 16 & 2013 & 20 & 7.22 & 73454 & 19879 & 337.7 & 95.53 & 824 & 251.61 \\
\hline 17 & 2014 & 31 & 18.22 & 75697 & 22122 & 352 & 109.83 & 858 & 285.61 \\
\hline 18 & 2015 & 32 & 19.22 & 78277 & 24702 & 380 & 137.83 & 883 & 310.61 \\
\hline
\end{tabular}

* We calculated the average annual minimum wage between 1999 and 2007

economics and social aspects of individual countries significantly. The negative phenomenon of labor emigration is deformation in the population structure of the native population. Emigration may reduce the number of educated, engaged and dynamic individuals in sending country and directly affect its productivity. The noticeable deficit of qualified workers appears in some regions, sectors, professions, deficit is mostly in the automotive, engineering, electrical, construction, IT sectors, trade and services, health, as well science and research. On the other hand, remittances, return migration and brain gain are the benefits of this phenomenon.

The main aim of our research was to explore the reasons for emigration to work from the Slovak Republic. In line with other researches we state that the working environment (e.g., the price of labor, the amount of contributions, and the behavior of employers to their employees) is the core reason for emigration. Unskilled workers leave their country most often because of low income or because they cannot find suitable employment in the domestic labor market. Leave of highly skilled labor force can affect the country significantly as opposed to unskilled labor which the country can quickly replace. State incurred significant costs on highly qualified workers, which they used abroad and not at home then.
The Slovak Republic has one of the biggest dynamics of the aging population in Europe, the outflow of labor force for work on foreign labor market may deteriorate significantly above question. It is time that government began to deal with specific issues not only at national level but especially at the regional level. Among those issues are, as it resulted from our study, as follows: satisfaction with work life, the level of employment in the regions and wages as well as services to citizens and their availability.

Many businesses have decided to employ foreigners because it is convenient for them. Frequently foreigners represent cheaper and more flexible labor force for the company. On the other hand, businesses are aware that they will not gain a stable workforce by employing foreigners. People come to other countries to obtain more favourable employment in comparison with the domestic labor market, mainly for a higher salary or also to get better professionalism and skills that they will use on domestic labor market later. The labor market has started to feel a significant labor shortage in all sectors in Slovakia in 2016. For this reason the employment of foreigners becoming actual also. The state would certainly be more beneficial to employ its citizens and reduce the number of unemployment, and it also has a non-economic context, especially social. It will be necessary to examine the 
mentioned issues concerning various aspects of people’s lives, not just with economic indicators.

\section{References}

Anelli M, Peri G (2017) Does emigration delay political change? Evidence from Italy during the Great Recession. Economic Policy, July: 551-596. https://doi.org/10.1093/epolic/eix006

Bahna M (2011) Migrácia po vstupe do Európskej únie. Bratislava: Slovenská akadémia vied.

Baršová A, Barša P (2005) Přistěhovalectví a liberální stát. Imigrační a integrační politiky v USA, západní Evropě a Česku. Brno: Medzinárodní politologický ústav.

Benda O (2011) Migrace pracovní síly - metla současné západní civilizace? HR Forum 4 (4) www.hrforum.cz/migrace-pracovni-sily-metla-soucasne-zapadni-civilizace/

Bilan Y (2012) Specificity of border labour migration. Transformations in Business and Economics 11 (2): 82-97.

Bilan Y, Cabelkova I (2015) Interdisciplinary approach to migration studies. Sotsiologicheskie Issledovaniya 9: 70-74.

Böcker A (1994) Chain migration over legally closed borders: settled migrants as bridgeheads and gatekeepers. Netherlands' Journal of Social Sciences 30 (2): 87-106.

Bolečeková M (2010) Migračná politika. Banská Bystrica: FPVaMV Univerzita Mateja Bela.

Czaika M, de Haas H (2013) The effectiveness of immigration policies. Population and Development Review 39 (3): 487508. https://doi.org/10.1111/j.1728-4457.2013.00613.x

Czaika A (2015) Migration in the age of the nation-state: migrants, refugees, and the National Order of Things. Alternatives: Global, Local, Political 39 (3): 151-163. https://doi. org/10.1177/0304375415570453

Čajka P, Jaroszewicz M, Strielkowski W (2014) Migration incentives and flows between Belarus, Moldova, Ukraine and the European Union: a forecasting model. Economics \& Ssociology 7 (4): 11-25. https://doi.org/10.14254/2071-789X.2014/7-4/1

Dibeh G, Fakih A, Marrouch W (2018). Decision to emigrate amongst the youth in Lebanon. International Migration 56 (1): 5-22. https://doi.org/10.1111/imig. 12347

Divinský B (2005) Zahraničná migrácia v Slovenskej republike: stav, trendy, spoločenské súvislosti. Bratislava: Friedrich Erbet Stiftung.

Divinský B, et al. (2011) Nové trendy a prognóza pracovnej migrácie v Slovenskej republike do roku 2020 s výhladom do roku 2050. Bratislava: TREXIMA spol. s. r. o.

Eurostat (2018) Migration and migrant population statistics http://ec.europa.eu/eurostat/statistics-explained/index.php/ Migration_and_migrant_population_statistics

Jeníček V, Foltýnet J (2010) Globální problémy světa v ekonomických souvislostech. Praha: C. H. Bec.
Jurčová D (2005) Migračné toky v Slovenskej republike http:// ec.europa.eu/ewsi/UDRW/images/items/docl_28845_ 86367376.pdf

Ortega F, Peri G (2013) The effect of income and immigration policies on international migration. Migration Studies 1 (1): 1-28. https://doi.org/10.1093/migration/mns004

Mboup G (2018) Urbanization and migration - two global mega trends: diversity, opportunities, and challenges. 51st session on sustainable cities, human mobility and international migration. United Nations www.un.org/en/development/ desa/population/pdf/commission/2018/documents/Presentation_GoraMboup.pdf

Pabedinskaitė A, Činčikaitė R (2016) Kiekybiniai modeliavimo metodai [Quantitative modeling methods]. Vilnius: Technika. https://doi.org/10.20334/1563-S

Saleh Mothana, O (a kol.) (2007) Vývojové tendencie vo vybraných oblastiach svetovej ekonomiky. Working papers 5 (2).

Soroková T (2010) Psychologicko-ekonomické aspekty oodlivu absolventov slovenských univerzít do zahraničia. Manažment podnikania a veci verejných 5 (12).

Strielkowskia W, Bilan Y (2016) Migration aspirations \& decisions: a comparative study of Turkey and Ukraine. Intellectual Economics 10 (1): 18-27. https://doi.org/10.1016/j. intele.2016.05.001

Szarucki M, Brzozowski J, Stankevičienè J (2016) Determinants of self-employment among Polish and Romanian immigrants in Germany. Journal of Business Economics and Management 17 (4): 598-612. https://doi.org/10.3846/16111699.2016.1202313

Štatisticky urad (2013) [Statistical Office of the SR (2013)] Vývoj obyvatelstva v Slovenskej republike a v krajoch. Bratislava: ŠÚ SR.

Thomas A (2016) Degrees of inclusion: free movement of labour and the unionization of migrant workers in the European Union. JCMS: Journal of Common Market Studies 54 (2): 408-425. https://doi.org/10.1111/jcms.12284

Vojtovič S (2013) The impact of emigration on unemployment in Slovakia. Inzinerine ekonomika [Engineering Economics] 24 (3): 207-216.

Willekens F, Zinn S, Leuchter M (2017) Emigration rates from sample surveys: an application to Senegal. Demography 54: 2159-2179. https://doi.org/10.1007/s13524-017-0622-y

Yeasmin N (2016) The determinants of sustainable entrepreneurship of immigrants in Lapland: an analysis of theoretical factors. Entrepreneurial Business and Economics Review 4 (1): 129-159. https://doi.org/10.15678/EBER.2016.040109

Zabarauskaitė R, Skačkauskienė I (2014) The survey of attitudes toward work by the unemployed in Lithuania. International Journal of Management - Theory and Applications (IREMAN) 2 (4): 109-115. 